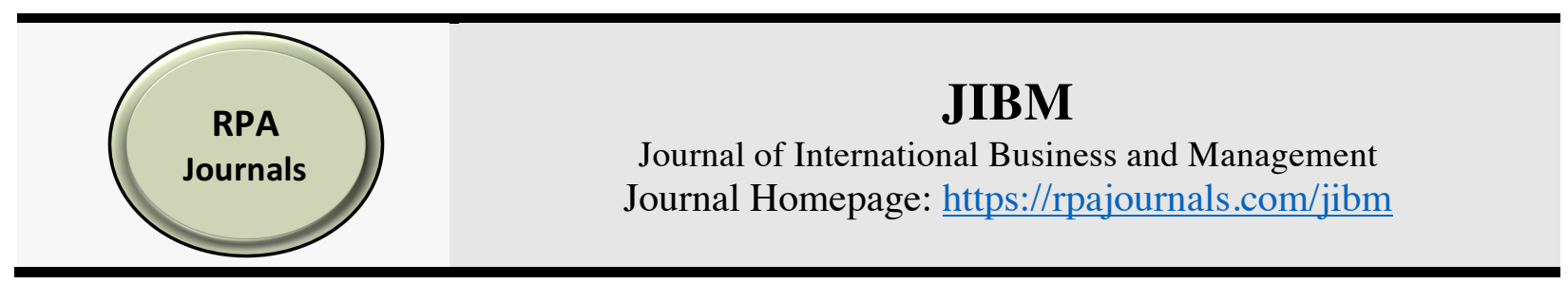

\title{
Benefit and Sacrifice Factors Determining Internet Banking Adoption in Iraqi Kurdistan Region
}

\author{
Ashty Rasull'", \\ Amer Hamzah Jantan², \\ Mass Hareeza Ali ${ }^{3}$, \\ Nor Siah Jaharudin 4 \\ Zurain Dato Mansor ${ }^{5}$ \\ Department of Management and Economics ${ }^{1,2,3,45}$ \\ Universiti Putra Malaysia (UPM), Malaysia $\sin ^{12,3,45}$
}

\begin{abstract}
Internet banking experience varies across different situations in various countries and, in turn, generate dissimilar attitudes and behaviours of banking customers. One region that is experiencing difficulties related to Internet banking and where bank managers remain unsuccessful in persuading bank customers to adopt Internet banking is Iraqi Kurdistan Region (IKR). To enhance the extant knowledge of the reasons behind this issue, the current research focused on identifying the determinants of Internet banking adoption in IKR and sought to investigate the effect of benefit factors (perceived usefulness, perceived ease of use, and perceived system quality) and sacrifice factors (perceived cost and perceived risk) on behavioural intention to use and, in turn, actual use of internet banking in IKR. To achieve this aim, this research conceptualized a model inspired by Technology Acceptance Model (TAM). The study conducted a quantitative approach and used a self-administrated questionnaire as the research instrument. Data were collected from 412 respondents. Structural Equations Modelling (SEM) was applied as the suitable inferential analytical method for analysing the data. The results generated revealed the significant role of perceived usefulness, perceived ease of use, perceived system quality and perceived risk on behavioural intention to use Internet banking. This research theoretically and practically contributed to knowledge through clarifying the perception of bank customers toward adopting Internet banking in IKR and revealing the importance of benefit and sacrifice factors in explaining behavioural intention to use Internet banking.
\end{abstract}

Keywords: Benefit Factors, Sacrifice Factors, Internet Banking Adoption.

*Corresponding author: Ashty Rasull*; Email: ashtyrasul@yahoo.com

DOI: https://doi.org/10.37227/jibm.2020.65

\section{Introduction}

The advent of new information and communication technologies within the financial industry has had a dramatic impact on customer services of banks. Indeed, the speed of the change in technology has more influence on the transformation in the banking industry than any other sector (Kirakosyan \& Danaiata, 2014). Among the various contemporary information and communication technologies 
utilized by banks, Internet banking is recognized as one of the most effective and practical business services in the world (Ariff et al., 2012). The growth and dynamism in Internet banking have impelled researchers to study the use of Internet banking and factors contributing to its adoption. Reviewing the literature reveals that this attempt has led to developing several theoretical models that seek to understand and predict the behavioural intention of customers using Internet banking (Santouridis and Kyritsi, 2014). One of the models that has been adopted by many scholars as the basis for developing new models in the area of Internet banking is Technology Acceptance Model (TAM) (Davis, 1989). Davis (1986) proposed TAM to gain understanding and predict customer adoption and acceptance of information systems. TAM suggests that individuals' behavioural intention for utilizing information technology is predicated on two beliefs: Perceived Usefulness and Perceived Ease of Use.

TAM fosters understanding customers' intentions to use Internet banking and antecedents for adopting this service. TAM is the most widely used instrument for assessing adoption of information systems by customers (Al-Sharafi et al., 2017). Since its introduction over 30 years ago, TAM has been continuously applied, modified, or combined with other models in various fields and kinds of information systems in different countries. Evidence shows that TAM is a reliable and valid construct for predicting $40 \%$ of information systems' usage (Abdulkadir et al., 2013), but that there is a need to include other attitudinal belief constructs to the original belief constructs of TAM to enhance its robustness and predictive power (Abdulkadir et al., 2013; Zhou, 2011). Therefore, several researchers have expanded TAM by incorporating additional variables or elements (e.g., Abdulkadir et al.., 2013; Al-Somali et al., 2009; Luarn \&Lin, 2005; Noronha \& Rao, 2017; Venkatesh \& Morris, 2000).

The past studies revealed that the impact of many variables on behavioural intention (Fadare, 2016; Khedmatgozar \& Shahnazi, 2018). Among those variables, perceived usefulness and perceived ease of use, as the original variables of TAM have consistently demonstrated their significant effects on intention theoretically and practically (Ariff et al., 2012; Al-Sharafi et al., 2017). Moreover, the literature affirms the important role of perceived system quality, perceived cost and perceived risk variables in adoption of information technology system (Chansaenroj \& Techakittiroj, 2015; Khedmatgozar \& Shahnazi, 2018; Namahoot \& Laohavichien, 2015). Mixed findings have been obtained in previous studies pertaining to the influence of these three factors on intention. Thus, further research is required to address the inconsistent findings and to make a comprehensive model of the attitude and behaviour of customers toward Internet banking adoption. Existing published research also indicates that researchers applying TAM to evaluate the attitude and behaviour of customers toward information technology system have not considered the variable of actual use. In fact, most of the studies only considered intention to use a service as the ultimate variable in predicting the behaviour of customers (AlSoufi \& Ali, 2014; Taleghani \& Taleghani, 2016). However, a crucial question that has been considered in TAM original models but has not wellstudied in the context of Internet banking is that whether behavioural intention to use Internet banking could indeed induce actual usage of this service.

Aside from the theoretical lacunae and limitations in the extant literature, concentration on Internet banking adoption in Iraqi Kurdistan Region (IKR) is needed. Internet banking research has been undertaken using samples from across the globe, while a country that has been noticeably absent from this empiricism is IKR (Singh \& Bradosti, 2015). Indeed, many IKR bank customers still prefer to go to the banks and do their financial transactions directly in the bank rather than using Internet banking (Singh \& Bradosti, 2015). Internet banking in IKR is not widespread yet, and many bank customers do not have the required awareness and knowledge to implement Internet banking (Singh $\&$ Bradosti, 2015). Accordingly, identifying factors that affect behavioural intention, and actual use of Internet banking, as well as understanding reasons behind the attitude and behaviour of customers toward IKR Internet banking appears necessary. Therefore, the current study tries to investigate the antecedents of behavioural intention to use Internet banking in IKR on the basis of two taxonomies of benefit and sacrifice factors using a holistic model to enhance understanding of attitude and behaviour of customers towards IKR Internet banking. In better expression, the current study aims to investigate the effects of benefit factors (perceived usefulness, perceived ease of use and perceived 
system quality) and sacrifice factors (perceived cost and perceived risk) on behavioural intention to use and, in turn, actual use of internet banking in IKR. Hopefully, the results obtained here can be generalized to Internet banking in other developing countries.

\section{Internet Banking}

\section{Literature Review}

Internet banking, or online banking, is "the service that allows consumers to perform banking transactions using a computer with an Internet connection" (Fathima \& Muthumani, 2015). The use of the Web in supporting banking transactions has been helpful in promoting interactive sessions between customers and banks. This service has been useful in enabling consumers to execute transactions, such as perusal of account balances, money transfer, and bill payment (Oppong et al., 2014).

The rapid adoption of Internet banking technology is prominent in the developed economies. Most banking institutions in the developed countries have moved away from the traditional forms of banking to undertake transactions over the internet. Most of them have a completely automated online system; thus, customers are likely to enjoy most, if not all, of the perceived benefits of Internet banking (Al-Qeisi \& Hegazy, 2015). Conversely, the rate of use of Internet banking is relatively lower in developing nations. The high level of technological advancements evident in developed nations is lacking in most developing. The attitude and behaviour of customers toward Internet banking in most developing nations are highly unpredictable (Shaikh \& Karjaluoto, 2015).

Internet banking research has been undertaken using samples from across the globe, while a country that has been noticeably absent from this empiricism is IKR (Singh \& Bradosti, 2015). Indeed, there is a lack of an effective modern banking system in IKR. The banking institutions have not established measures to ensure that their services meet the quality standards of a modern banking institution. The weak banking system has also reduced its effectiveness, causing the public to lose trust in their services (Al-Najjar \& Jawad, 2016). The weak banking culture and lack of regulation have generated a cash economy that hinders funding and investments required for Internet banking development in banks (The Kurdistan Tribune, 2011). The consistent failures in the development of policies and political laxity have revamped the banking sectors and influenced the pace of Internet banking development. Similarly, customer literacy and lack of knowledge have also been issues in banking procedures. Such characteristics become barriers to technological improvement in the IKR banking and competition. Also, customer convenience has been affected adversely with the relative paucity of Internet banking introduction into banks. Specifically, Kurdistans are not able to avail themselves of the services if the responsible authorities are not involved in providing such offerings (Singh \& Bradosti, 2015).

\section{Technology Acceptance Model (TAM)}

Davis (1986) introduced the technology acceptance model (TAM), which is one of the most cited theoretical frameworks to predict the adoption and use of new information technology (software and information systems) within organizations. Davis (1989) argued that people adopt an application primarily because of the functions it performs, and secondarily because of the ease or difficulty associated with making the system perform these functions. The model provides a basis for tracking the impact of external factors on internal beliefs, attitude, and behavior (Davis et al., 1989). The original TAM was presented in terms of two important determinants for systems use: perceived ease of use (PEOU) and perceived usefulness (PU). In this model, attitude toward using a system predicts users' behavioral intention to use, which determines actual system use (see Figure 1). 


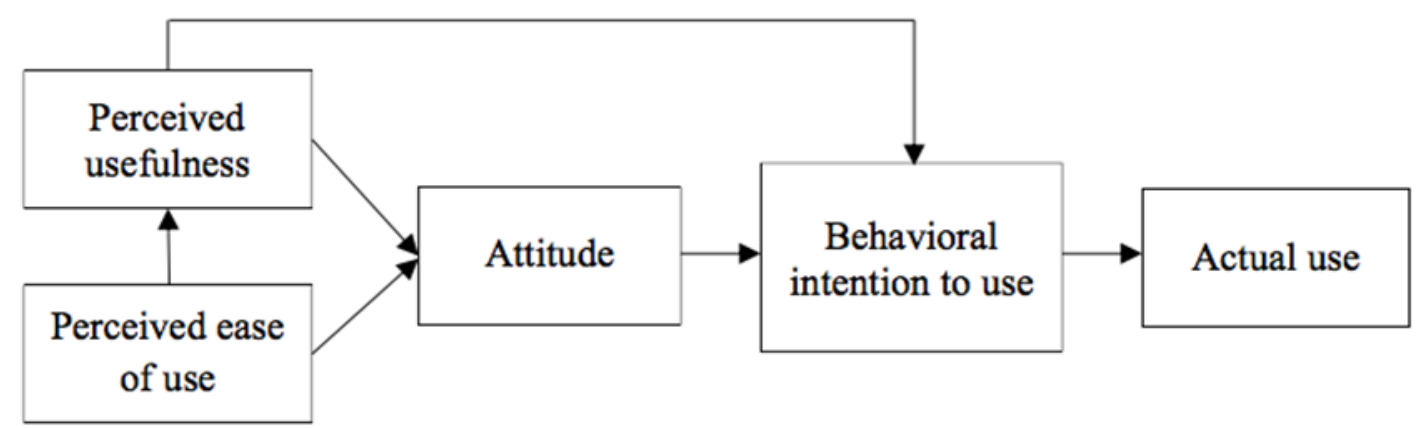

Figure 1: Technology Acceptance Model (TAM) (Davis, 1989)

Behavioural intention represents a persons' readiness to perform a given behaviour and is the primary predictor of actual behaviour (Ajzen, 2006). In the context of Internet banking, behavioural intention is a customer's likelihood to utilise online transactions through Internet banking (Chen et al., 2002).

\section{Factors Affecting Internet Banking Adoption}

The literature has suggested that there are various factors that can promote or discourage the adoption of Internet banking among consumers (Budiwati \& Kurniasih, 2014; Chuwa, 2015). In this study, to strengthen TAM and utilize it in the context of Internet banking, five antecedent variables of intention are considered. These variables can be subsumed under two domains: benefit and sacrifice factors. Benefit factors refer to the value customers desired (e.g., service quality). Sacrifice factors refer to monetary and non-monetary considerations (Alsheikh, 2013). Martins and Monroe, (1994) argued that 'buyers' perceptions of value represent a trade-off between the quality and benefits they perceive in the product relative to the sacrifice they perceived by paying the price". Accordingly, to satisfy Internet banking customers, banks should increase the perceived benefits of using their Internet banking and/or decrease its perceived sacrifices (e.g., cost and risk).

\section{Benefit Factors}

In TAM, perceived ease of use and perceived usefulness are the benefit factors (Alsheikh, 2013). In this research, to reinforce the ability of TAM in predicting Internet banking adoption, perceived system quality is added to the model as another variable representing benefit factors.

\section{Perceived usefulness and Perceived ease of use}

Perceived usefulness is defined as the extent to which a person believes that using a particular system will enhance his or her job performance (Davis et al., 1989). It is the belief that using a specific technology would contribute in improving the task that is being conducted (Al-Sharafi et al., 2017). Of direct relevance to the present study, Lee (2009) revealed that customers acquire direct and indirect benefits from Internet banking. While the direct benefits are more tangible, such as increased transparency of financial transactions and instant transactions, indirect benefits are intangible, such as 24-hour service and ability to transact banking from anywhere in the world.

Perceived ease of use is defined as the extent to which a person believes that using a particular system will be free of effort (Davis et al., 1989). This construct refers to customers' ease of accessing the bank's technology. Saade and Bahli (2005) mentioned that, while potential individuals using the technology understand that it could be beneficial, they could 
feel that it is difficult to employ. As such, performance advantages of utilising the technology could be offset by the efforts required to utilise it.

As TAM has been implemented by some scholars to investigate technology adoption, the effects of perceived usefulness and perceived ease of use as the origins of TAM on intention have been investigated by the past studies. For instance, Nasri and Charfeddine (2012) used TAM to evaluate Internet banking adoption and observed that perceived usefulness and perceived ease of use predict behavioural intention to use Internet banking. Santouridis \& Kyritsi (2014) discerned that the most significant determinant of behavioural intention to use Internet banking was perceived usefulness. To a lesser extent, perceived ease of use was also found to have a significant effect on behavioural intention to use Internet banking. Al-Sharafi et al. (2017) determined that perceived ease of use did not predict behavioural intention to use Internet banking. Perceived usefulness, through the mediating role of perceived trust, though, partially affected the behavioural intention to use Internet banking. Ariff et al. (2012) indicated that perceived usefulness and perceived ease of use had a significant relationship with intention.

As reviewed, most of the studies have resulted in significant and positive effects of perceived usefulness and perceived ease of use on behavioural intention to use Internet banking (Al-Somali et al., 2009; Nasri \& Charfeddine, 2012; Santouridis \& Kyritsi, 2014). Although the literature tends to proclaim the importance of perceived usefulness and perceived ease of use in predicting behavioural intention to use Internet banking, findings have been inconsistent (e.g., Al-Sharafi et al., 2017). Therefore, to develop an enhanced model of Internet banking adoption and to clarify the ambiguity in the literature in terms of the effects of these two variables on adoption of Internet banking, examining the roles of perceived usefulness and perceived ease of use in this context seems warranted.

\section{Perceived System Quality}

Perceived system quality is customers' perception of information retrieval and delivery of a system (Phuong \& Trang, 2018). It refers to the perceived performance of Internet banking system in terms of reliability, ease of use, convenience, functionality, and other system metrics (DeLone \& McLean, 2003). The relationship between perceived system quality and intention has been considered in the previous studies. In this context, Noronha \& Rao (2017) found that system quality was significantly and positively related to customer intention to use the service. Budiwati and Kurniasih (2014) analysed factors affecting successful use of the Internet banking. The findings indicated system quality does not affect use. In another study, Sachithra \& Sritharan (2017) investigated the effect of system quality and customer satisfaction on usage of Internet banking. The results indicated that system quality significantly and positively affected customer satisfaction, which, in turn, had a significant positive impact on usage of Internet banking. Namahoot \& Laohavichien (2015) discovered that service and system quality affects trust and behavioural intention to use Internet banking. Phuong \& Dai Trang (2018) revealed that system quality affects behavioural intention through the mediating role of customer satisfaction.

As mentioned, previous research has shown the importance of perceived system quality in predicting intention to use information technology system has been demonstrated (DeLone \& McLean, 2003; Noronha \& Rao, 2017; Phuong \& Dai Trang, 2018), however the findings are mixed. Accordingly, to provide further understanding about the relationship between perceived system quality and intention to use Internet banking, further investigation is needed. 


\section{Sacrifice Factors}

Two sacrifice factors of perceived risk and perceived cost are also added into the model.

\section{Perceived Cost}

Luarn and Lin (2005) defined perceived cost as "the extent to which a person believes that using technology will cost money". Sathye (1999) argued that financial costs negatively affect adoption of Internet banking and considered two types of cost related to its adoption. The first type is the cost of Internet, such as the expense of computers and Internet connection; the second type is the bank costs and charges. Relatedly, Silvio et al. (2014) opined that compared with other alternatives to ease of Internet banking adoption, technological innovations should, therefore, be reasonably priced.

The relationship between perceived cost and behavioural intention has been emphasised by some scholars. They believe that financial costs have negative impact on adoption of information technology system. In this line, $\mathrm{Yu}$ (2012) found that intention to use information technology system is significantly influenced by perceived financial cost. Chansaenroj \& Techakittiroj (2015) revealed that the perceived usefulness, perceived ease of use, perceived cost and perceived risk affect intention to use information technology system. In another study, Chuwa (2015) investigated attitudes of bank customers toward adopting Internet banking. Based on the results, psychological factors including perceived compatibility, perceived relative advantage, perceived complexity, perceived cost and perceived risk affect adopting Internet banking. AlSoufi \& Ali (2014) revealed that the variables of perceived risk and perceived cost do not affect the users' intention to use information technology system.

\section{Perceived risk}

Littler and Melanthiou (2006) regard perceived risk as "the lack of trust and potential side effects influencing the purchase of an article or services". In the context of Internet banking, Kim et al. (2008) considered perceived risk as "the bank customer's thought and belief in the likelihood of having an adverse outcome and consequence in online transactions". It is subjectively strongminded perception of loss by an online bank user in considering a precise deal (Fadare, 2016). Security and privacy are substantial hindrances to Internet banking adoption (Sathye, 1999), thus representing a kind of perceived risk. Illegal activities can occur quickly in the absence of physical interaction between customers and malefactors. Accordingly, Internet banking customers are subject to potential economic losses via illegitimate exterior entry (Littler \& Melanthiou, 2006).

Some scholars have argued that perceived risk is an important antecedent of intention. For example, Demirdogen et al. (2010) through a comparative analysis of perceived risk among users and non-users of Internet banking revealed that perceived risk (financial, safety, and psychological risk) of users was higher than non-users. Fadare (2016) discerned that perceived risk negatively affected behavioural intention to use Internet banking. Interestingly, however, Lafraxo et al. (2018) ascertained that perceived risk did not affect intention. In another study, Khedmatgozar \& Shahnazi (2018) found that there was significant relationships between a set of perceived risk variables and intention to adopt Internet banking by the corporate clients. Sathye (1999) assessed the adoption of Internet banking by customers and identified lack of awareness and security concerns as the main obstacles to adopt Internet banking.

Indeed, reviewing the past studies reveals that the number of investigations that sought to evaluate possible effects of perceived risk and cost on behavioural intention to use 
Internet banking are limited. Second, the results observed in prior work reveal that these relationships remain unclear. Some researchers believe that perceived cost and perceived risk have negative significant effects on behavioural intention to use information technology system (e.g., Yu, 2012; Chansaenroj \& Techakittiroj, 2015; Chuwa, 2015; Taleghani \& Taleghani, 2016), but other scholars argue that these relationships are insignificant (Al Soufi \& Ali, 2014; Fadare, 2016). This ambiguity in the literature suggests need for further exploration.

\section{Conceptual Framework}

This research investigates the effect of benefit factors (perceived usefulness, perceived ease of use and perceived system quality) and sacrifice factors (perceived cost and perceived risk) on behavioural intention to use and, in turn, actual use of internet banking. Reviewing the literature demonstrated the rationale behind hypothesizing these relationships and revealed the necessity to examine these relationships according to the mixed findings of the past studies and the ambiguity in existing those relations. As mentioned before, the research model is inspired by TRM (Davis, 1989) and tires to develop it. TRM provides a basis for tracking the impact of external factors on internal beliefs, attitude, and behavior (Davis et al., 1989). The original TAM considers two main determinants for adoption of a system: perceived ease of use (PEOU) and perceived usefulness (PU). In the study's model, attitude toward using the service directly predicts intention to use the service, which then leads to actual use of the service. Based on literature reviewing, this research hypothesizes that in addition to Perceived Ease of Use (PEOU) and Perceived Usefulness (PU), Perceived System Quality (PSQ), Perceived cost (PC) and Perceived risk (PR) also could affect behavioural intention to use Internet banking. The preceding discussion leads to developing the following 6 hypotheses:

H1: Perceived usefulness (PU) has a significant, positive effect on behavioural intention to use Internet banking (BIUB).

H2: Perceived ease of use (PEOU) has a significant, positive effect on behavioural intention to use Internet banking (BIUB).

H3: Perceived system quality (PSQ) has a significant, positive effect on behavioural intention to use Internet banking (BIUB).

H4: Perceived cost (PC) has a significant, negative effect on behavioural intention to use Internet banking (BIUB).

H5: Perceived risk $(P R)$ has a significant, negative effect behavioural intention to use Internet banking (BIUB).

H6: Behavioural intention to use Internet banking (BIUB) has a significant, positive effect on actual use (AU) of this service. 


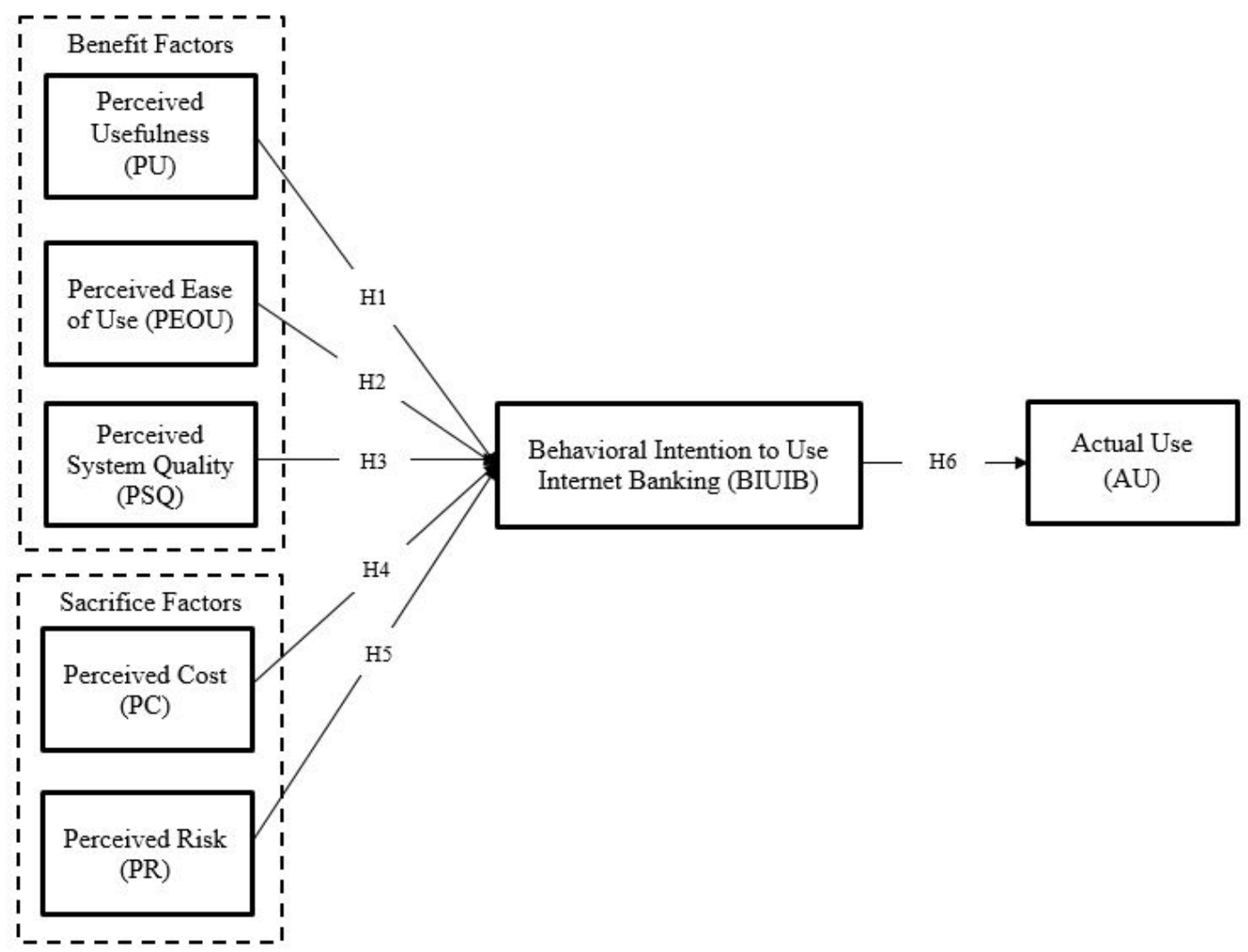

Figure 2: Conceptual framework of the research

\section{Research Method}

The approach of this quantitative study is positivist, wherein hypothesis are tested based on the results generated by the analysis of the data collected from the research questionnaire.

\section{Instrumentation}

This research implemented questionnaire as the suitable tool to collect the required information for achieving its aim. To prepare the research questionnaire, the valid and standard sources were considered. It must be noted that, for selecting the items this research was benefited from the knowledge and expertise of IT experts who considered the necessities of internet banking and focused on the considerations of the Iraqi Kurdistan region to localize the questionnaire.

The questionnaire instrument designed and used for the current research comprised 42 unique questions that were answered using a 5-point Likert scale, with response options ranging from 1 (strongly agree) to 5 (strongly disagree). Table 1 shows the constructs, the number of items related to each constructs and the sources were used to select the items. 
Table 1: Description of Questionnaire Elements

\begin{tabular}{|c|l|c|c|}
\hline \multicolumn{1}{|c|}{ Constructs } & No. of Items & References \\
\hline 1 & Perceived Usefulness (PU) & 7 Items & $\begin{array}{c}\text { Wang et al. (2003); Pikkarainen et al. } \\
\text { (2004); Özer, Argan \& Argan, (2013) }\end{array}$ \\
\hline 2 & Perceived Ease of Use (PEOU) & 8 Items & $\begin{array}{c}\text { Wang et al. (2003); } \\
\text { Pikkarainen et al., (2004) }\end{array}$ \\
\hline 3 & Perceived System Quality (PSQ) & 8 Items & $\begin{array}{c}\text { Al-Somali et al. (2009) } \\
\text { (20) }\end{array}$ \\
\hline 5 & Perceived Cost (PC) & 4 Items & $\begin{array}{c}\text { Luarn and Lin (2005); Yang et al. (2011); } \\
\text { Abrahão et al. (2016) }\end{array}$ \\
\hline 6 & $\begin{array}{l}\text { Behavioural Intention to Use } \\
\text { Internet Banking (BIUIB) }\end{array}$ & 5 Items \\
\hline 7 & Actual Use (AU) & $\begin{array}{c}\text { Featherman and Pavlou (2003); Alalwin et } \\
\text { al. (2018) }\end{array}$ \\
\hline
\end{tabular}

\section{Sampling and data collection}

\section{Population}

The study's population consists of bank customers who have used Internet banking services in IKR banks. There are 44 banks in IKR, 14 state- banks and 30 privately-owned banks. The population of IKR is 5,100,000 (Iraqi Kurdistan, 2015). According to Singh and Bradosti (2015), only 20\% of IKR's residences are using Internet banking, thus representing approximately $1,020,000$ people.

\section{Sampling}

The current study employed probability sampling method and, in particular, random sampling. In this method, each member of the population has an equal chance of being selected as a subject. According to Sekaran and Bougie (2010), sample size selection defines the level of confidence and precision employed in the research. Krejcie and Morgan (1970) provided a table to assist researchers in selection of a reasonable sample size to reduce the probability of any error. Based on the table prepared by Krejcie and Morgan (1970), the sample size for a target population of 1020000 is 384, which is considered sufficient for structural equation modelling-the statistical technique that was used in data analysis for this study.

\section{Data Collection}

The eligible respondents of the study were the bank customers who had used Internet banking services in IKR banks. Those individuals should likely have conducted online transactions with the banking industry, irrespective of length of experience. Such consumers should had an idea regarding information technology, and they likely had some degree of awareness of technological factors associated with the banking industry. To distribute the questionnaire, Erbil as IKR's capital city was chosen as the research locale.

Questionnaires were distributed face to face to the bank customers. Collecting a large number of surveys in a few days was unlikely, as it may affect the banks' operations. 
Therefore, the schedule for information gathering was decided in accordance to availability of participants and bank management. After participants were selected and the dates for data collection were determined, the questionnaire was distributed between them and the required data was collected.

\section{Analysis and Discussion}

After the required data was collected, the process of data analysis was begun. The initial phase of data analysis was data screening. In general 438 bank customers have answered the research questionnaire from 5 banks in Erbil: Kurdistan International Bank $(n=131)$, Cihan Bank ( $\mathrm{n}=93)$, Al Baraka Bank $(\mathrm{n}=67)$, Trade Bank of Erbil $(\mathrm{n}=108)$, and Byblos Bank ( $=39$ ), but due to missing and outlier issues, the number was reduced to 412 completed questionnaires.

\section{Structural Equation Modelling (SEM)}

After preparing the data, the analytical process was followed by performing Structural Equation Modelling (SEM). In this research Partial Least Squares SEM, which focuses on analysis of covariance was implemented using Smart-PLS 3 software. Employing the recommended two-stage analytical procedures by Anderson and Gerbing (1988), the measurement model (validity and reliability of the measures) were followed by an examination of the structural model (testing the hypothesized relationship).

\section{Reliability of the model}

In any quantitative survey, the indicators are expected to demonstrate sufficient reliability. Therefore, the first step of analysis was to assess internal reliability, most often using Jöreskog's (1971) composite reliability (CR). Cronbach's alpha is another measure of internal consistency reliability; it produces, though, lower values than composite reliability. Dijkstra and Henseler (2015) also proposed rho_A as an approximately exact measure of construct reliability; it usually lies between Cronbach's alpha and the composite reliability. In general, for reliability higher values show higher levels of reliability. Nunnally and Bernstein (1994) recommended a minimum reliability value of 0.7 . In this research, to test the reliability of the model, three criteria of composite reliability (CR), Cronbach's alpha and rho_A were examined. Shown in Table 2 are the results of testing construct reliability of the model.

Table 2: Construct Reliability

\begin{tabular}{|l|c|c|c|}
\hline \multicolumn{1}{|c|}{ Construct } & $\begin{array}{c}\text { Cronbach's } \\
\text { Alpha }\end{array}$ & rho_A & $\begin{array}{c}\text { Composite } \\
\text { Reliability } \\
\text { (CR) }\end{array}$ \\
\hline Perceived Usefulness & 0.926 & 0.927 & 0.940 \\
\hline Perceived Ease of Use & 0.916 & 0.917 & 0.932 \\
\hline Perceived System Quality & 0.895 & 0.906 & 0.916 \\
\hline Perceived Cost & 0.841 & 0.855 & 0.891 \\
\hline Perceived Risk & 0.819 & 0.825 & 0.831 \\
\hline $\begin{array}{l}\text { Behavioural intention to use Internet } \\
\text { banking }\end{array}$ & 0.899 & 0.902 & 0.925 \\
\hline Actual Use & 0.889 & 0.891 & 0.919 \\
\hline
\end{tabular}


As portrayed in Table 2, the entire values related to the three measures of Cronbach's alpha, rho_A and composite reliability (CR) are higher than 0.7 ; as such, the reliability of the model appears to be adequate.

\section{Validity of the model}

Apart from reliability, validity assessment is equally important in any research. There are two types of validity criteria assessment, convergent and discriminant validity.

\section{Convergent Validity}

Convergent validity is the extent to which the construct converges to explain the variance of its items (Hair et al., 2019). The metric used for evaluating a construct's convergent validity is the average variance extracted (AVE). AVE serves as a measure of unidimensionality (Fornell \& Larcker 1981). If the first factor, which is extracted from a set of indicators, appears to explain more than one-half of their variance, there may not be any second and equally important factor. Therefore, an AVE of 0.5 or higher is regarded as acceptable (Fornell and Larcker, 1981). The second metric used to test the convergent validity is composite reliability (CR). A model has convergent validity when for every factor CR $>$ AVE (Ramayah et al., 2017). Illustrated in Table 3 are the results of testing convergent validity of the model.

Table 3: Convergent validity

\begin{tabular}{|l|c|c|}
\hline \multicolumn{1}{|c|}{ Construct } & $\begin{array}{c}\text { Average } \\
\text { Variance } \\
\text { Extracted (AVE) }\end{array}$ & $\begin{array}{c}\text { Composite } \\
\text { Reliability (CR) }\end{array}$ \\
\hline Perceived Usefulness & 0.692 & 0.940 \\
\hline Perceived Ease of Use & 0.630 & 0.932 \\
\hline Perceived System Quality & 0.579 & 0.916 \\
\hline Perceived Cost & 0.673 & 0.891 \\
\hline Perceived Risk & 0.581 & 0.831 \\
\hline $\begin{array}{l}\text { Behavioural Intention to Use Internet } \\
\text { Banking }\end{array}$ & 0.712 & 0.925 \\
\hline Actual Use & 0.693 & 0.919 \\
\hline
\end{tabular}

As Table 3 reveals, the all values of AVE related to the constructs are higher than 0.5 . In addition, the values of composite reliability for each construct are greater than their commensurate AVE values. Accordingly, the model indicates convergent validity.

\section{Discriminant Validity}

The next step of analysis is to examine discriminant validity, which is the extent to which a construct is empirically distinct from other constructs in the structural model (Hair et al., 2019). Henseler et al. (2015) introduced the heterotrait-monotrait (HTMT) ratio of the correlations as the measure for assessing discriminant validity. The HTMT is considered as the mean value of the item correlations across constructs relative to the (geometric) mean of the average correlations for the items measuring the same construct. When HTMT values are high the issue of discriminant validity appears (Hair et al., 2019). Henseler et al. (2015) 
proved that the HTMT score ranges between -1 to 1 are acceptable. Revealed in Table 4 are the results generated for testing discriminant validity.

Table 4: Discriminant Validity

\begin{tabular}{|c|c|c|c|c|c|c|c|}
\hline & 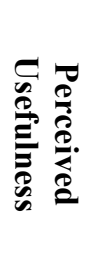 & 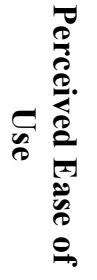 & 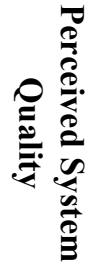 & 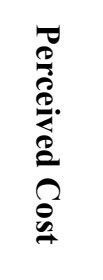 & 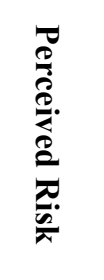 & 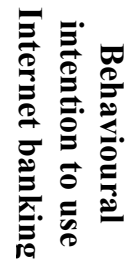 & 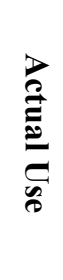 \\
\hline Perceived Usefulness & & & & & & & \\
\hline Perceived Ease of Use & 0.766 & & & & & & \\
\hline Perceived System Quality & 0.632 & 0.768 & & & & & \\
\hline Perceived Cost & 0.210 & 0.311 & 0.421 & & & & \\
\hline Perceived Risk & 0.172 & 0.191 & 0.286 & 0.405 & & & \\
\hline $\begin{array}{l}\text { Behavioural intention to use } \\
\text { Internet banking }\end{array}$ & 0.662 & 0.776 & 0.704 & 0.289 & 0.134 & & \\
\hline Actual Use & 0.638 & 0.735 & 0.717 & 0.222 & 0.222 & 0.752 & \\
\hline
\end{tabular}

According to the results reported in Table 4, all HTMT scores are between -1 and 1, so, discriminant validity has been ascertained.

\section{Collinearity}

When assessing structural models, saying that there are no collinearity issues in the structural model (or inner model) is critical. This typically occurs when two variables, which are hypothesized to have a causal relationship, result in measuring the same construct. In other words, predictor-criterion collinearity may sometimes subtly mislead the findings as it can weaken the strong causal effects in the structural model (Henseler et al., 2016). To assess the collinearity issue, the variance inflation factor (VIF) is often used. VIF should not be greater than 5; otherwise, it indicates that there might be a potential collinearity problem (Hair et al., 2019). Reported in Table 5 are the results of testing constructs collinearity.

Table 5: Collinearity Statistics of the Constructs

\begin{tabular}{|l|ccc|}
\hline & & & \\
& & & \\
& & & \\
Perceived Usefulness & 2.069 & 2.080 & \\
Perceived Ease of Use & 2.659 & 3.054 & \\
Perceived System Quality & 2.201 & 2.524 & \\
Perceived Cost & 1.252 & 1.255 & \\
Perceived Risk & 1.155 & 1.156 & \\
Behavioural intention to use & & & 1.000 \\
Internet banking & & & \\
\hline
\end{tabular}

The values of VIF for all constructs are less than 5, thus demonstrating that there is not any collinearity problems regarding the constructs. 


\section{Testing the Research Hypotheses}

After collinearity has been determined not to be an issue, and the measurement model is deemed to be of sufficient quality, the analysis then moves to an assessment of the structural model. Path coefficients or beta coefficients $(\beta)$ are the most important results of a structural model. They indicate the change in a dependent variable resulting from a unit change in an independent variable with the condition that all the other independent variables remain constant (Henseler et al., 2016). A path coefficient is regarded as significant (i.e., unlikely to purely result from sampling error) if its confidence interval does not include the value of zero or if the $p$-value is below the pre-defined $\alpha$-level.

In addition, the predictive power of the research model can be evaluated by means of the coefficient of determination score $\left(\mathrm{R}^{2}\right) . \mathrm{R}^{2}$ is a measure of the model's predictive accuracy and can also be viewed as the combined effect of the exogenous variables on the endogenous variables. $\mathrm{R}^{2}$ ranges from 0 to 1 , with higher values indicating greater explanatory power. As a guideline, $\mathrm{R}^{2}$ values of $0.75,0.50$, and 0.25 are regarded as substantial, moderate, and weak (Hair et al., 2019).

Researchers can also assess how the removal of a certain predictor construct affects an endogenous construct's $R^{2}$ value. This metric is the $f^{2}$ effect size and is somewhat redundant to the size of the path coefficients. It is a measure used to assess the relative impact of a predictor construct on an endogenous construct (Cohen, 1988). According to Cohen (1988), $\mathrm{f}^{2}$ values of $0.35,0.15$, and 0.02 are considered large, medium, and small effect sizes. Depicted in Figure 3 are the measurement model results produced by SmartPLS 3.2.8.

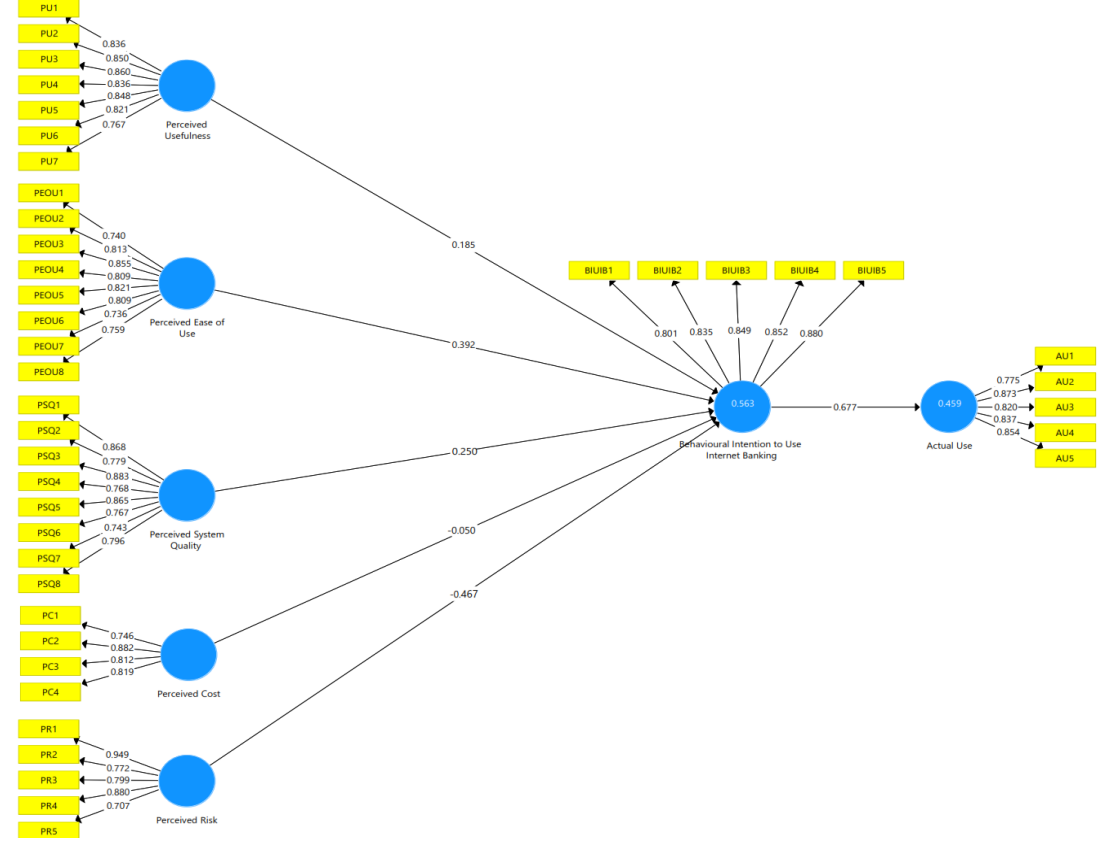

Figure 3: Measurement model results

The loading values of the observed variables on their related latent variables are portrayed in Figure 3. As indicated, the loading values of the entire observed variables on their related constructs are higher than 0.7 , which demonstrates the strength of the observed variables in predicting their related factors. Shown in Table 6 are the structural model results for direct relationships between the variables of the study. 
Table 6: Structural Model Results for direct relationships between the variables

\begin{tabular}{|c|c|c|c|c|c|c|}
\hline Relationship & $\begin{array}{l}\text { Std. } \\
\text { Beta } \\
(\beta)\end{array}$ & $\begin{array}{c}\text { Std. } \\
\text { Deviatio } \\
n\end{array}$ & $\begin{array}{c}t- \\
\text { Value }\end{array}$ & $\begin{array}{c}\text { p - } \\
\text { Value }\end{array}$ & $\mathbf{f}^{2}$ & Status \\
\hline $\begin{array}{l}\text { Perceived Usefulness -> } \\
\text { Behavioural intention to use } \\
\text { Internet banking }\end{array}$ & 0.185 & 0.058 & 2.954 & 0.003 & $\begin{array}{c}0.03 \\
4\end{array}$ & $\begin{array}{c}\text { Signifi } \\
\text { cant }\end{array}$ \\
\hline $\begin{array}{l}\text { Perceived Ease of Use -> } \\
\text { Behavioural intention to use } \\
\text { Internet banking }\end{array}$ & 0.392 & 0.056 & 6.150 & 0.000 & $\begin{array}{c}0.06 \\
6\end{array}$ & $\begin{array}{c}\text { Signifi } \\
\text { cant }\end{array}$ \\
\hline $\begin{array}{l}\text { Perceived System Quality - } \\
>\text { Behavioural intention to } \\
\text { use Internet banking }\end{array}$ & 0.250 & 0.059 & 4.832 & 0.005 & $\begin{array}{c}0.02 \\
7\end{array}$ & $\begin{array}{c}\text { Signifi } \\
\text { cant }\end{array}$ \\
\hline $\begin{array}{l}\text { Perceived Cost -> } \\
\text { Behavioural intention to use } \\
\text { Internet banking }\end{array}$ & -0.050 & 0.037 & 1.088 & 0.299 & $\begin{array}{c}0.00 \\
3\end{array}$ & $\begin{array}{l}\text { Non- } \\
\text { signific } \\
\text { ant } \\
\end{array}$ \\
\hline $\begin{array}{l}\text { Perceived Risk -> } \\
\text { Behavioural intention to use } \\
\text { Internet banking }\end{array}$ & -0.467 & 0.069 & 8.128 & 0.000 & $\begin{array}{c}0.16 \\
9\end{array}$ & $\begin{array}{c}\text { Signifi } \\
\text { cant }\end{array}$ \\
\hline $\begin{array}{l}\text { Behavioural intention to use } \\
\text { Internet banking -> Actual } \\
\text { Use }\end{array}$ & 0.677 & 0.036 & 19.428 & 0.000 & $\begin{array}{c}0.84 \\
9\end{array}$ & $\begin{array}{c}\text { Signifi } \\
\text { cant }\end{array}$ \\
\hline
\end{tabular}

Note: $R^{2}$ Behavioural intention to use Internet banking $=0.563 ; \mathrm{R}^{2}$ Actual Use $=0.459$

As Table 6 shows, the direct relationships between Perceived Usefulness $(\beta=0.185, \mathrm{t}=$ $\left.2.954, \mathrm{p}<0.01, \mathrm{f}^{2}=0.034\right)$, Perceived Ease of Use $\left(\beta=0.392, \mathrm{t}=6.150, \mathrm{p}<0.01, \mathrm{f}^{2}=\right.$ $0.066)$, Perceived System Quality $\left(\beta=0.250, \mathrm{t}=4.832, \mathrm{p}<0.01, \mathrm{f}^{2}=0.027\right)$ and Perceived Risk $\left(\beta=-0.467, \mathrm{t}=8.128, \mathrm{p}<0.01, \mathrm{f}^{2}=0.169\right)$ with Behavioural intention to use Internet banking are significant. On the other hand, the direct relationship between Perceived Cost and Behavioural intention to use Internet banking is not significant $(\beta=-0.050, t=1.088, p$ $\left.=0.299, \mathrm{f}^{2}=0.003\right)$. The results also show that there is a significant relationship between Behavioural intention to use Internet banking and Actual Use $(\beta=0.677, \mathrm{t}=19.428, \mathrm{p}<$ $\left.0.01, \mathrm{f}^{2}=0.849\right)$.

\section{Discussion of the research hypothesis}

The results generated by SEM indicated that perceived usefulness and perceived ease of use significantly and positively affect behavioural intention to use Internet banking. Thus, the research hypotheses H1 (Perceived usefulness (PU) has a significant, positive effect on behavioural intention to use Internet banking) and H2 (Perceived ease of use (PEOU) has a significant, positive effect on behavioural intention to use Internet banking) were accepted. A preponderance of previous empiricism on the relationship between perceived usefulness and perceived ease of use with behavioural intention to use Internet banking has resulted in significant and positive effect of the aforementioned variables on behavioural intention to use Internet banking (e.g., Al-Somali et al., 2009; Nasri \& Charfeddine, 2012; Ariff et al., 2012; Santouridis \& Kyritsi, 2014). Therefore, the research finding is consistent with the results of prior studies. Indeed, as Snoj et al. (2004) proffered about the perceived usefulness 
of internet banking, users utilise a system because of its attributes that drive value: the utility provided by the combination of attributes minus the disutility represented by any sacrifices required to use the system. Eze et al. (2013) emphasized that, if customers perceive Internet banking systems as helpful, then they are likely to accept it.

In terms of the perceived ease of use of internet banking Santos (2003) said, to create favourable customer perceptions about using a bank's website, an easy-to- remember URL address, uncomplicated site navigability, a well-organized format and concise and understandable content, terms, and conditions are requisite. Raman (2008) also recommended that banks focus on Web site navigation and applicable functions to provide users with ease of use. This research brought another proof for the arguments of the cited scholars.

The results related to the relationship between perceived system quality and behavioural intention to use Internet banking observed a significant and positive relationship between these two variables. Thus the research hypothesis H3 (Perceived System Quality (PSQ) has a significant, positive effect on behavioural intention to use Internet banking) was accepted too. This finding is consistent with those of prior studies (e.g., Namahoot \& Laohavichien, 2015; Noronha \& Rao, 2017; Phuong \& Dai Trang, 2018). Accordingly, this research affirmed the idea of the prior scholars who believed that the quality of the system is a key element in the effective use of an Internet banking service (George and Kumar, 2014). Banks require websites that present an understandable system with minimum parameters, thus fostering user access of relevant information. Shneiderman \& Plaisant (2010), though, argued that online users are dissatisfied with unsecured payment gateways and poor navigation. The lack of personalization could also dissatisfy online users. Users do not utilize the website if system quality does not meet their expectation, even if information quality is high. In general, users have high expectations about system quality (Shneiderman \& Plaisant, 2010).

In addition, the effect of perceived cost on behavioural intention to use Internet banking resulted in a negative but insignificant relationship. Therefore, the research hypothesis H4 (Perceived cost (PC) has a significant, negative effect on behavioural intention to use Internet banking) was rejected. The research finding is consistent with the findings of previous research (e.g., AlSoufi \& Ali, 2014; Taleghani \& Taleghani, 2016). However, it was inconsistent with the results in some prior studies (e.g., Yu, 2012; Chansaenroj \& Techakittiroj, 2015; Chuwa, 2015). Prior work has also found that perceived cost negatively influences users' intention to use an information technology system (Luarn \& Lin, 2005; Cruz, et al., 2010). Users of Internet banking often compare the perceived cost with the value of adoption when discerning whether to adopt it (Sathye, 1999; Pagani, 2004). Wessels (2009) argued that the higher the cost of the good or service, the lower the level of demand, which partially explains how costs affect consumer behaviour. Cost considerations may become particularly relevant in the context of Internet banking. Customers may believe that the service is not necessary, although it may be perceived as a "nice-to-have" option.

The results also indicated that Perceived risk significantly and negatively influences behavioural intention to use Internet banking. Thus, the research hypothesis H5 (Perceived risk (PR) has a significant, negative effect behavioural intention to use Internet banking) was accepted. This finding is compatible with that of prior research on the effect of perceived risk on behavioural intention to use Internet banking (e.g., Sathye, 1999; Demirdogen et al., 2010; Fadare, 2016). This relationship can be justified using extant work. Internet banking subjects customers to potential economic losses via illegitimate exterior entry (Littler \& Melanthiou, 2006). In using technology, customers often perceive that using an online 
service is risky, as disclosure of private information or a bank's misuse of private information is possible (Sathye, 1999; Fadare, 2016). Goyal and Goyal (2012) proposed that adopting Internet banking is related to the degree of privacy and security customers perceive. Cruz et al. (2010) also averred that perceived risk is the greatest concern that users of information technology system have.

The results also showed that the relationship between Intention and Actual Use of Internet Banking is significant. Thus, the research hypothesis H6 (Behavioural intention to use Internet banking has a significant, positive effect on actual use of this service) was accepted. This finding provides further support for the applicability of the Technology Acceptance Model (TAM) (Davis, 1989) and helps fill the gap of knowledge in the context of Internet banking adoption. Prior studies, however, essentially have only considered behavioural intention to use as the outcome variable and have not considered actual use in their proposed models (e.g., Nasri \& Charfeddine; 2012; Santouridis \& Kyritsi, 2013; AlSharafi et al., 2017). This finding supports this idea that behavioural intention to use Internet banking leads to actual use of this system.

\section{Conclusion}

This study set out to address Internet banking adoption in IKR. It investigated the effect of benefit factors and sacrifice factors on behaviour intention to use and, in turn, actual use of Internet banking in the Iraqi Kurdistan banking sector. Bank customers' unwillingness to adopt Internet banking in IKR and the lack of knowledge and ambiguity about the factors effecting behavioural intention to use Internet banking led to focussing on this topic.

Through a quantitative approach, this research investigated customer perceptions about the usefulness, ease of use, system quality, cost, and risk they tolerate when they are using Internet banking. The findings of the research demonstrated that certain study variables could be subsumed into two kinds of benefit factors (perceived usefulness, perceived ease of use and perceived system quality) and sacrifice factor (perceived risk) have significant effects on behavioural intention to use Internet banking. Moreover, it was shown that the benefit factors of perceived usefulness, perceived ease of use and perceived system quality positively affect behavioural intention to use Internet banking, and the sacrifice factors of perceived risk and perceived cost negatively affect it. Therefore, the current study contributed to the literature through identifying the benefit and sacrifice factors affecting internet banking adoption wherein the subject was ambiguous.

Also the current research, through considering actual use as the ultimate variable of the study, brought further evidence for that the supposition that intention could lead to actual usage. Considering that the most extant work related to Internet banking adoption has considered behavioural intention to use as the ultimate variable, the finding here thus contributed to the literature through signifying the role of actual use in adoption of Internet banking.

Accordingly, the research findings show the significant role of customer perceptions toward adoption of Internet banking. Bank customers in IKR need Internet banking service that engenders a positive perception in terms of usefulness, ease of use and system quality. Also, their demand for Internet banking service could decrease if their concerns about risk and cost are excessive. In a broad sense, IKR bank customers embrace Internet banking when they perceive it as a useful, easy, and understandable service that has no risks and does not jeopardize their security and privacy. They adopt Internet banking when they perceive that the cost of this service is fair and worth it. Therefore, bank managers in IKR should seek to eliminate pessimism and negative perceptions of their bank customers about using Internet 
banking service through providing enhanced facilities, improved system design, fair value, and secure systems, thus augmenting the level of customer willingness and desire to use Internet banking as an especially viable alternative to face-to-face banking.

\section{References}

Abdulkadir, N., Galoji, S. I., \& Razak, R. B. A. (2013). An investigation into the adoption of mobile banking in Malaysia. American Journal of Economics, 3(3), 153-158.

Ajzen, I. (2006) The theory of planned behavior - diagram taken from the TPB Model home page: http://people.umass.edu/aizen/tpb.diag.html.

Al-Najjar, S. M., \& Jawad, M. K. (2016). Measuring Customers' Perceptions and Readiness to Accept E-Commerce in Iraq: An Empirical Study. Journal of Marketing Management, 4(1), 151-162.

Al-Qeisi, K., \& Hegazy, A. (2015). Consumer online behaviour: A perspective on internet banking usage in three non-western countries. Procedia economics and finance, 23, 386-390.

Al-Sharafi, M. A., Arshah, R. A., Herzallah, F. A., \& Alajmi, Q. (2017). The Effect of Perceived Ease of Use and Usefulness on Customers Intention to Use Online Banking Services: The Mediating Role of Perceived Trust. International Journal of Innovative Computing, 7(1).

Alsheikh, L. H. (2013). Determinant of Customer Intention to Adopt Mobile Banking Services in Saudi Arabia (Doctoral dissertation, Universiti Putra Malaysia).

Al-Somali, S. A., Gholami, R., \& Clegg, B. (2009). An investigation into the acceptance of online banking in Saudi Arabia. Technovation, 29(2), 130-141.

AlSoufi, A., \& Ali, H. (2014). Customers perception of mbanking adoption in Kingdom of Bahrain: an empirical assessment of an extended tam model. arXiv preprint arXiv: 1403.2828 .

Anderson, J. C., \& Gerbing, D. W. (1988). Structural Equation Modeling in Practice: A Review and Recommended Two-Step Approach. Psychological Bulletin, 103 (May), 411-423.

Ariff, M. S. M., Yeow, S. M., Zakuan, N., Jusoh, A., \& Bahari, A. Z. (2012). The effects of computer self-efficacy and technology acceptance model on behavioral intention in internet banking systems. Procedia-Social and Behavioral Sciences, 57, 448-452.

Budiwati, CH., \& Kurniasih, L. (2014). Analysis of Internet Banking (I-Banking) Success Using a Respecification of Delone \& Mclean Information Success Model (Case Study at Permata Bank, Surakarta, Indonesia). International Proceedings of Economics Development and Research, 76, 78-82.

Chansaenroj, P., \& Techakittiroj, R. (2015). Factors Influencing the Intention to Use Mobile Banking Services in Bangkok. Proceedings of ISER $4^{\text {th }}$ International Conference, Bangkok, Thailand, $16^{\text {th }}$ August 2015, ISBN: 978-93-85465-78-9.

Chen, L. D., Gillenson, M. L., \& Sherrell, D. L. (2002). Enticing online consumers: an extended technology acceptance perspective. Information \& management, 39(8), 705719.

Chuwa, G. (2015). Factors Influencing the Adoption of Internet Banking by Small and Medium Enterprises (SMEs) in Nyamagana District, Mwanza-Tanzania.

Cohen, J. (1988). Statistical Power Analysis for the Behavioral Sciences, Lawrence Erlbaum, Mahwah, NJ.

Cruz, P., Neto, L.B.F., Muñoz-Gallego, P., Laukkanen, T. (2010), Mobile banking rollout in 
emerging markets: Evidence from Brazil. International Journal of Bank Marketing, 28(5), 342-371.

Davis, F. D. (1986). A technology acceptance model for empirically testing new end-user information systems, Phd Dissertation, Massachusetts Institute of Technology, Sloan School of Management.

Davis, F. D. (1989). Perceived usefulness, perceived ease of use and user acceptance of information technology. MIS Quarterly, 13, 319-340.

Demirdogen, O., Yaprakli, S., Yilmaz, M. K., \& Husain, J. (2010). Customer Risk Perceptions of Internet Bankıng-A Study in Turkey. The Journal of Applied Business Research, 26(6), 57-68.

Delone, W. H., \& McLean, E. R. (2003). The DeLone and McLean model of information systems success: a ten-year update. Journal of management information systems, 19(4), 9-30.

Dijkstra, T. K., \& Henseler, J. (2015). Consistent and asymptotically normal PLS estimators for linear structural equations. Computational statistics \& data analysis, 81, 10-23.

Einwiller, S., \& Will, M. (2001). The Role of Reputation to Engender Trust in Electronic Markets. Proceedings of the 5th International Conference on Corporate Reputation, Identity, and Competitiveness, France.

Eze, C., Manyeki, J., Ling, Y., \& Lee, H. (2013). Factors Affecting Internet Banking Adoption among young Adults: Evidence from Malaysia. International Conference on Social Science and Humanity IPEDR, 5, 65-82.

Fadare, O. A. (2016). A survey on perceived risk and intention of adopting internet banking. The Journal of Internet Banking and Commerce, 21(1), 1-21.

Fathima, Y. A., \& Muthumani, S. (2015). User acceptance of banking technology with special reference to internet banking. Journal of Theoretical \& Applied Information Technology, 73(1).

Fornell, C., and Larcker, D. F. (1981). Evaluating Structural Equation Models with Unobservable Variables and Measurement Error. Journal of marketing research. 8, 3950 .

George, A., \& Kumar, G. G. (2014). Impact of service quality dimensions in internet banking on customer satisfaction. Decision, 41(1), 73-85.

Goyal, V. M., \& Goyal, G. (2012). Customer perception towards Internet banking wrf to private and foreign banks in India. International Journal of Computing \& Business Research, 2229-6166.

Hair, J. F., Risher, J. J., Sarstedt, M., \& Ringle, C. M. (2019). When to use and how to report the results of PLS-SEM. European Business Review, 31(1), 2-24.

Henseler, J., Hubona, G., \& Ray, P. A. (2016). Using PLS path modeling in new technology research: updated guidelines. Industrial management \& data systems, 116(1), 2-20.

Iraqi Kurdistan, 2015. Iraqi Kurdistan. [Online] Available at: http://www.bcci.bg/resources/files/.pdf [Accessed 16th July 2017].

Jaffar, A. A., Ghareb, M. I., \& Sharif, K. H. (2016). The Challenges of Implementing ECommerce in Kurdistan of Iraq. Journal of University of Human Development, 2(3), 528-533.

Jöreskog, K. G. (1971). Simultaneous factor analysis in several populations. Psychometrika, 36(4), 409-426.

Khedmatgozar, H. R., \& Shahnazi, A. (2018). The role of dimensions of perceived risk in adoption of corporate internet banking by customers in Iran. Electronic Commerce Research, 18(2), 389-412. 
Kirakosyan, K., Dănăiaţă, D. (2014). Communication management in electronic banking. Better communication for better relationship. Procedia -Social and Behavioral Sciences, 124, $361-370$.

Krejcie, R. V., \& Morgan, D. W. (1970). Determining sample size for research activities. Educational and psychological measurement, 30(3), 607-610.

Lafraxo, Y., Hadri, F., Amhal, H., \& Rossafi, A. (2018). The Effect of Trust, Perceived Risk and Security on the Adoption of Internet Banking in Morocco. In Proceedings of the 20th International Conference on Enterprise Information Systems (ICEIS 2018) Volume 2, pages 497-502.

Lee, K. C., \& Chung, N. (2009). Understanding factors affecting trust in and satisfaction with mobile banking in Korea: A modified DeLone and McLean's model perspective. Interacting with computers, 21(5-6), 385-392.

Littler, D. \& Melanthiou, D. (2006). Consumer perceptions of risk and uncertainty and the implications for behaviour towards innovative retail services: the case of internet banking. Journal of Retailing and Consumer Services, 13(6), 431-443.

Luarn, P., and Lin, H.-H. (2005).Toward an understanding of the behavioral intention to use mobile banking. Computers in Human Behavior, 21(6), 873-891.

Namahoot, K. S., \& Laohavichien, T. (2015). Quality management and trust of internet banking in Thailand. International Journal of Scientific and Technology Research, 4(9), 257-262.

Nasri, W., \& Charfeddine, L. (2012). Factors affecting the adoption of Internet banking in Tunisia: An integration theory of acceptance model and theory of planned behavior. The Journal of High Technology Management Research, 23(1), 1-14.

Noronha, A. K., \& Rao, P. S. (2017). Effect of Website Quality on Customer Satisfaction and Purchase Intention in Online Travel Ticket Booking Websites. Management, 7(5), 168-173.

Nunnally, J. C., \& Bernstein, I. H. (1994). The assessment of reliability. Psychometric Theory, 3(1), 248-292.

Oppong, P., Adjei, H., \& Poku, K. (2014). The Role of Information Technology in Building Customer Loyalty in Banking: (A Case Study of Agricultural Development Bank Ltd., SUNYANI). British Journal of Marketing Studies, 2(4), 9-29.

Özer, A., Argan, M. T., \& Argan, M. (2013). The effect of mobile service quality dimensions on customer satisfaction. Procedia-Social and Behavioral Sciences, 99, 428-438.

Pagani, M. (2004). Determinants of adoption of third generation mobile multimedia services. Journal of interactive marketing, 18(3), 46-59.

Phuong, N. N. D., \& Dai Trang, T. T. (2018). Repurchase Intention: The Effect of Service Quality, System Quality, Information Quality, and Customer Satisfaction as Mediating Role: A PLS Approach of M-Commerce Ride Hailing Service in Vietnam. Marketing and Branding Research, 5(2), 78-91.

Pikkarainen, T., Pikkarainen, K., Karjaluoto, H., \& Pahnila, S. (2004). Consumer acceptance of online banking: an extension of the technology acceptance model. Internet research, 14(3), 224-235.

Raman, M., Stephenaus, R., Alam, N., \& Kuppusamy, M. (2008). Information technology in Malaysia: E-service quality and update of Internet banking. Journal of Internet Banking and Commerce, 13(2), 1-18.

Ramayah, T., Yeap, J. A., Ahmad, N. H., Halim, H. A., \& Rahman, S. A. (2017). Testing a confirmatory model of Facebook usage in SmartPls using consistent PLS. International Journal of Business and Innovation, 3(2), 1-14. 
Saadé, R., \& Bahli, B. (2005). The impact of cognitive absorption on perceived usefulness and perceived ease of use in on-line learning: an extension of the technology acceptance model. Information \& management, 42(2), 317-327.

Sachithra, R. U., \& Sritharan, S. (2017). System quality and usage of internet banking functions: role of customer satisfaction. International Conference on Advanced Marketing, 22, 24.

Santos, J. (2003). E-service quality: A model of virtual service quality dimensions. Journal of Managing Service Quality. 13(3), 233-246.

Santouridis, I., \& Kyritsi, M. (2014). Investigating the determinants of Internet banking adoption in Greece. Procedia Economics and Finance, 9, 501-510.

Sathye, M. (1999). Adoption of Internet banking by Australian consumers: An empirical investigation. International Journal of Bank Marketing. 17(7), 324-334.

Sekaran, U., \& Bougie, R. (2006). Research method for business. Salemba Empat, Jakarta.

Shaikh, A. A., \& Karjaluoto, H. (2015). Mobile banking adoption: A literature review. Telematics and Informatics, 32(1), 129-142.

Shneiderman, B., \& Plaisant, C. (2010). Designing the user interface: strategies for effective human-computer interaction. Pearson Education India.

Singh, U. S., \& Bradosti, H. (2015). Acceptability of Banking Operations in Iraqi Kurdistan. Research Journal of Finance and Accounting, 6(9), 276-286.

Silvio, J., Camilleri, J. C., \& Fenech, M. D. (2014). Service Quality And Internet Banking Perceptions of Maltese Retail Bank Customers, Bank of Valletta Review, 48, 1-17.

Taleghani, M., \& Taleghani, A. (2016). The study of influencing factors on customers 'decision to use of mobile banking based on sms services (case study: the branches of governmental banks in Rasht city-northern of Iran). Quantitative Methods in Economics, 17(4), 149-159.

The Kurdistan Tribune (2011). Revival of banking sector in Iraq and the Kurdistan Region. The Kurdistan Tribune, 5 Augustus.

Venkatesh, V., \& Morris, M. G. (2000). Why don't men ever stop to ask for directions? Gender, social influence, and their role in technology acceptance and usage behavior. MIS quarterly, 115-139.

Wessels, B. (2009). Understanding the Internet: A socio-cultural perspective. Macmillan International Higher Education.

Yu, C. S. (2012). Factors affecting individuals to adopt mobile banking: Empirical evidence from the UTAUT model. Journal of electronic commerce research, 13(2), 104-121.

Zhou, T. (2011). An empirical examination of initial trust in mobile banking. Internet Research, 21(5), 527-540. 